\title{
Efektivitas perasan daun seledri (Apium graveolens Linn.) sebagai pembersih gigi tiruan terhadap pertumbuhan Candida albicans pada basis gigi tiruan nilon termoplastik
}

\author{
Dhilan Purna Aji ${ }^{1}$, Achmad Gunadi', Tantin Ermawati ${ }^{*}$
}

\author{
1Departemen Prostodonsia, Fakultas Kedokteran Gigi Universitas Jember, Indonesia \\ ${ }^{2}$ Departemen Biomedik, Fakultas Kedokteran Gigi Universitas Jember, Indonesia
}

*Korespondensi: tantin.ermawati@unej.ac.id

Submisi: 30 Juli 2020; Penerimaan: 29 Desember 2020; Publikasi online: 31 Desember 2020

DOI: $10.24198 / j \mathrm{~kg} . \mathrm{v} 32 \mathrm{i} 3.28877$

\begin{abstract}
ABSTRAK
Pendahuluan: Basis gigi tiruan nilon termoplastik merupakan alternatif pengganti basis gigi tiruan resin akrilik. Pembersihan gigi tiruan diperlukan untuk menjaga basis gigi tiruan agar tetap bersih dari kontaminasi mikroorganisme. Daun seledri merupakan bahan alam yang memiliki kandungan flavonoid, saponin, tanin, dan minyak atsiri yang sudah terbukti bersifat antijamur. Penelitian sebelumnya hanya melihat zona hambat saja. Tujuan penelitian adalah menganalisis efektivitas perasan daun seledri sebagai pembersih gigi tiruan terhadap pertumbuhan Candida albicans pada basis gigi tiruan nilon termoplastik. Metode: Eksperimental laboratoris dengan rancangan penelitian post-test only control group design. Sampel nilon termoplastik berbentuk cakram dengan diameter $10 \mathrm{~mm}$ dan tebal $2 \mathrm{~mm}$ sebanyak 25 dibagi menjadi 5 kelompok. Sampel dikontaminasi dengan $C$. albicans setelah direndam dalam kontrol negatif (akuades) selama 6 jam, kontrol positif (tablet effervescent) selama 15 menit, dan perasan daun seledri konsentrasi 25,50 , dan $100 \%$ selama 6 jam. Sampel selanjutnya diletakkan dalam media sabouraud dextrose broth (SDB). Pengujian efektivitas perasan daun seledri dilakukan dengan menentukan nilai absorbansi kekeruhan media SDB menggunakan spektrofotometer. Data dianalisis menggunakan oneway ANOVA dan Least Significant Difference (LSD). Hasil: Nilai konsentrasi C. albicans pada kelompok kontrol negatif mendapatkan hasil $0,380 \times 10^{8} \mathrm{CFU} / \mathrm{mL}$, kontrol positif mendapatkan hasil $0,310 \times 10^{8} \mathrm{CFU} /$ $\mathrm{mL}$, perasan daun seledri konsentrasi $25 \%$ mendapatkan hasil $0,243 \times 10^{8} \mathrm{CFU} / \mathrm{mL}$, konsentrasi $50 \%$ mendapatkan hasil $0,160 \times 10^{8} \mathrm{CFU} / \mathrm{mL}$, dan konsentrasi $100 \%$ mendapatkan hasil $0,236 \times 10^{8} \mathrm{CFU} / \mathrm{mL}$. Simpulan: Perasan daun seledri efektif sebagai pembersih gigi tiruan untuk menghambat pertumbuhan C. albicans, dengan konsentrasi yang efektif sebesar $50 \%$.
\end{abstract}

Kata kunci: Nilon termoplastik, perasan daun seledri, Candida albicans.

The effectiveness of celery leaf juice (Apium graveolens Linn.) as a denture cleaner against the growth of Candida albicans on thermoplastic nylon denture base

\section{ABSTRACT}

Introduction: Thermoplastic nylon denture base is an alternative to the acrylic resin denture base. Denture cleaning is needed to keep the denture base clean from contamination by microorganisms. Celery leaves are natural ingredients that contain flavonoids, saponins, tannins, and essential oils that have been proven to have antifungal properties. Previous research only observed the inhibitory zone. This research was aimed to analyse the effectiveness of celery leaf juice as a denture cleaner against the growth of Candida albicans on thermoplastic nylon denture base. Methods: Experimental laboratory with a posttest only control group design was conducted towards 25 disc-shaped thermoplastic nylon samples with a diameter of $10 \mathrm{~mm}$ and a thickness of $2 \mathrm{~mm}$, and divided into five groups. Samples were contaminated with C. albicans after immersion in the negative control (aquadest) for 6 hours, positive control (effervescent tablets) for 15 minutes, and celery leaf juice with the concentrations of 25, 50, and 100\% for 6 hours. The sample was then placed in the Sabouraud-dextrose broth (SDB) medium. The effectiveness of celery leaf juice was tested by determining the absorbance value of SDB media turbidity using a spectrophotometer. Data were analysed using one-way ANOVA and Least Significant Difference (LSD). Results: The concentration value of C. albicans in the negative control group was $0.380 \times 108 \mathrm{CFU} / \mathrm{mL}$, the positive control was $0.310 \times 108 \mathrm{CFU} / \mathrm{mL}$, the juice of celery leaves with the concentration of $25 \%$ was $0.243 \times 108$ CFU $/ \mathrm{mL}$, the concentration of $50 \%$ was $0.160 \times 108 \mathrm{CFU} / \mathrm{mL}$, and the concentration of $100 \%$ was 0.236 $\times 108 \mathrm{CFU} / \mathrm{mL}$. Conclusion: Celery leaf juice is effective as a denture cleaner to inhibit the growth of $\mathrm{C}$. albicans, with an effective concentration of $50 \%$.

Keywords: Thermoplastic nylon, celery leaf juice, Candida albicans. 


\section{PENDAHULUAN}

Riset Kesehatan Dasar menyatakan bahwa prevalensi kehilangan gigi di Indonesia yaitu sebesar $19 \% .{ }^{1}$ Kehilangan gigi dapat memberikan masalah pada kesehatan gigi dan mulut di masyarakat yang akan menyebabkan gangguan pada fungsi pengunyahan, bicara, estetis, dan bahkan hubungan sosial. ${ }^{2}$ Kehilangan gigi yang terjadi dapat diatasi dengan cara pembuatan protesa atau gigi tiruan. ${ }^{3}$ Gigi tiruan adalah suatu alat tiruan yang digunakan untuk menggantikan seluruh atau sebagian gigi asli yang sudah hilang dan mengembalikan perubahan-perubahan struktur jaringan gigi geligi.$^{4-6}$ Komponen yang dimiliki oleh gigi tiruan lepasan salah satunya adalah basis gigi tiruan yang dapat terbuat dari bahan akrilik, metal akrilik, dan termoplastik. ${ }^{7,8}$

Basis gigi tiruan mengalami perkembangan sebagai alternatif pengganti basis gigi tiruan resin akrilik, yaitu dengan bahan nilon termoplastik. ${ }^{9}$ Material dasar nilon termoplastik adalah poliamida yang berasal dari asam diamina dan monomer asam dibasic. ${ }^{10}$ Nilon termoplastik memiliki keuntungan yaitu tidak menggunakan cengkraman logam, estetik yang baik, dan mudah diterima oleh pasien yang memiliki alergi terhadap resin akrilik. ${ }^{11}$ Nilon termoplastik juga memiliki kekurangan yaitu mudah menyerap air sehingga akan menyebabkan terjadinya porositas. ${ }^{12}$ Porositas pada nilon termoplastik menyebabkan Candida albicans akan berkolonisasi dengan mudah. Kolonisasi $C$. albicans ini dapat diatasi dengan cara melepas dan merendam pada larutan pembersih gigi tiruan salah satunya yaitu dengan perasan daun seledri. ${ }^{12,13}$

Gigi tiruan yang digunakan secara terusmenerus tanpa pembersihan yang adekuat dapat menyebabkan terjadinya akumulasi plak. Salah satu mikroorganisme yang dapat ditemukan pada plak tersebut adalah Candida albicans. C. albicans merupakan flora normal di rongga mulut yang pada kondisi tertentu, seperti menurunnya sistem keseimbangan tubuh dan gangguan keseimbangan flora rongga mulut, dapat bersifat patogen dan menyebabkan denture stomatitis. ${ }^{14}$

Proliferasi jamur dapat menyebabkan bau mulut, perubahan warna pada basis gigi tiruan, penumpukan kalkulus, karies, penyakit periodontal, dan denture stomatitis. ${ }^{15}$ Gigi tiruan dapat dibersihkan dengan bahan aktif tambahan yang berfungsi sebagai antimikroba. ${ }^{16}$

Beberapa tahun terakhir, peneliti banyak mengembangkan bahan alam sebagai senyawa biologi aktif dalam pembuatan obat. ${ }^{17}$ Salah satu bahan alam yang dapat digunakan adalah tanaman seledri (Apium graveolens Linn.). Seledri sering digunakan oleh banyak orang sebagai bumbu masak dan bahan makanan. Seiring perkembangan zaman selain bermanfaat sebagai penyedap makanan, seledri juga memiliki kandungan zat aktif yang berpotensi untuk menghambat mikroorganisme patogen yang ada di dalam rongga mulut. Tanaman seledri mengandung flavonoid $1,7 \%$, saponin $0,36 \%$, tanin $1 \%$, dan minyak atsiri $0,33 \% .^{18}$ Penggunaan daun seledri sebagai bahan alam yang berkhasiat sebagai obat dapat digunakan sebagai alternatif pembersih gigi tiruan yang efektif menurunkan jumlah koloni C. albicans. ${ }^{13}$ Potensi antijamur dari seledri telah diuji terhadap Trichphyton longifuss, C. albicans, Aspergillus flavus, Microsporum canis, Fusarium solani, dan C. glabrata. ${ }^{19}$

Pembuatan air perasan daun seledri dapat dilakukan sebagai alternatif pembersih gigi tiruan. Banyak peneliti memilih air perasan daun seledri karena tidak membutuhkan alat yang mahal dan cara pembuatannya yang tidak rumit. ${ }^{13}$ Penelitian Ardelia dkk. ${ }^{13}$, juga menyatakan bahwa perasan daun seledri dengan konsentrasi 25,50 , dan $100 \%$ dapat menghambat pertumbuhan $C$. albicans. ${ }^{11}$ Penelitian yang dilakukan Ardelia dkk. ${ }^{13}$, hanya melihat seberapa besar zona hambat yang dihasilkan, oleh sebab itu peneliti ingin melihat efektifitas perasan daun seledri sebagai pembersih gigi tiruan terhadap pertumbuhan $C$. albicans pada basis gigi tiruan nilon termoplastik. Tujuan penelitian adalah menganalisis efektivitas perasan daun seledri sebagai pembersih gigi tiruan terhadap pertumbuhan Candida albicans pada basis gigi tiruan nilon termoplastik.

\section{METODE}

Penelitian ini adalah penelitian eksperimental laboratoris dengan menggunakan rancangan the post test only control group design. Penelitian ini dilaksanakan di Laboratorium Tanaman Politeknik Negeri Jember, Laboratorium Teknologi Kedokteran Gigi, Laboratorium Mikrobiologi, dan Laboratorium Bioscience Fakultas Kedokteran Gigi Universitas 
Jember pada bulan Desember 2019-Januari 2020.

Sampel penelitian yang digunakan yaitu cakram nilon termoplastik (Valplast, China) yang tidak dilakukan pemolesan. Cakram berbentuk lingkaran dengan diameter $10 \mathrm{~mm}$ dan tebal 2 $\mathrm{mm}$. Cakram yang digunakan dalam penelitian ini sebanyak 25 yang dibagi menjadi 5 kelompok, yaitu cakram nilon termoplastik yang direndam dalam kontrol negatif, kontrol positif, perasan daun seledri 25,50 , dan $100 \%$.

Pembuatan cakram nilon termoplastik dilakukan dengan cara membuat cetakan model master yang akan ditanam pada kuvet (Gambar $1 \mathrm{~A}$ dan 1B). Model master yang telah ditanam dipasangkan sprue dan digodok hingga didapatkan mould space (Gambar 1C dan 1D). Mould space yang telah terbentuk kemudian diisi menggunakan bahan nilon termoplastik yang telah disiapkan (Gambar 2A). Cakram yang telah terbentuk dirapikan dan diukur ketebalannya (Gambar 2B). ${ }^{20,21}$ Cakram kemudian disterilisasi menggunakan autoclave pada suhu $121^{\circ} \mathrm{C}$ selama 15 menit (Gambar 2C). Cakram yang telah disterilisasi akan dilakukan perendaman pada saliva buatan selama 1 jam dan dilakukan pembilasan menggunakan larutan phosphate buffer saline (PBS) sebanyak 2 kali. Suspensi $C$. albicans kemudian dipersiapkan dan cakram direndam serta diinkubasi selama 24 jam (Gambar 2D). Cakram yang telah diinkubasi kemudian direndam dalam kontrol negatif selama 6 jam, kontrol positif selama 15 menit, dan perasan daun seledri 25, 50, dan 100\% selama 6 jam (Gambar 3A dan 3B). Kontrol negatif yang digunakan yaitu akuades dan kontrol positif yang digunakan yaitu (Dent-a-clear, China) yang memiliki bahan aktif sodium bicarbonate, potassium caroate, sodium perborate, citric acid, PEG 6000, sodium lauryl sulfate, aroma mint, sodium benzoate, dan menthol. ${ }^{22,23}$

Perasan daun seledri yang digunakan dibuat sendiri oleh peneliti dengan cara mengambil tanaman seledri dari Perkebunan Jubung di

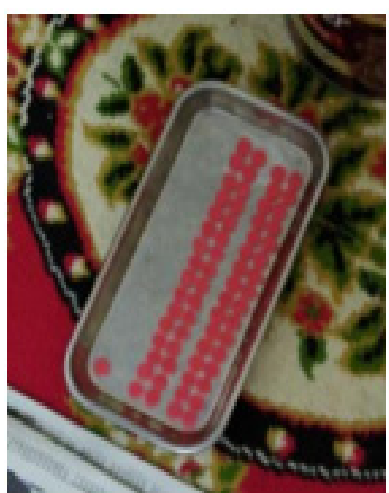

A

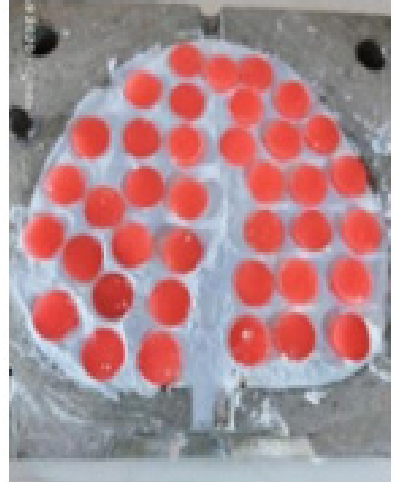

B

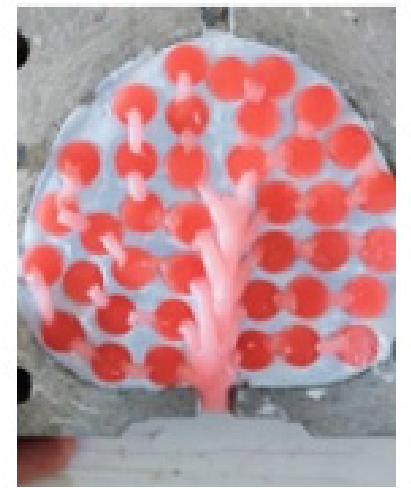

C

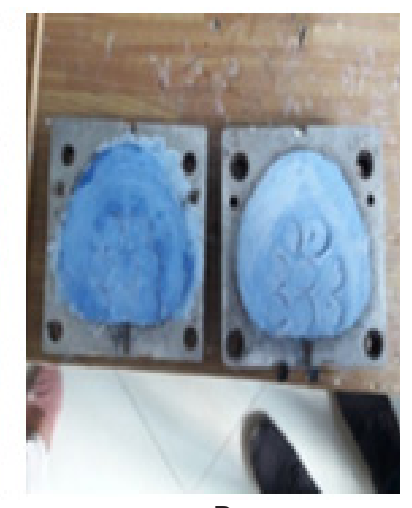

D

Gambar 1. A. Model master; B. Model master ditanam dalam kuvet; C. Model master dipasangkan sprue; D. Mould space setelahpembuangan lilin.(Sumber: Dokumentasi pribadi)

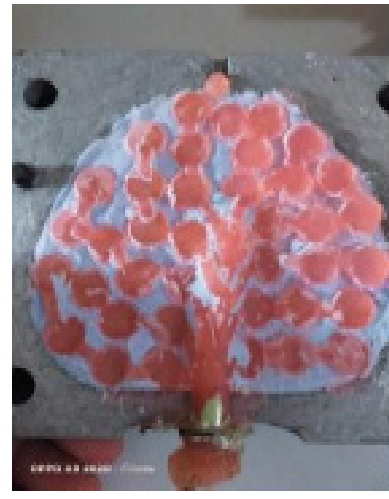

A

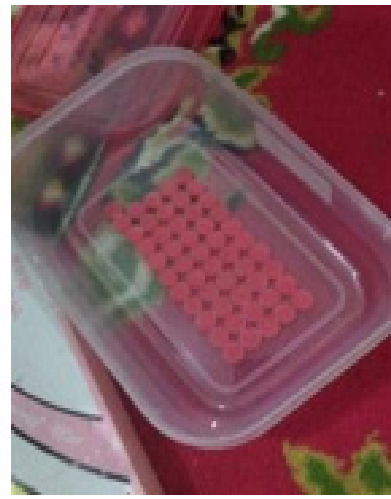

B

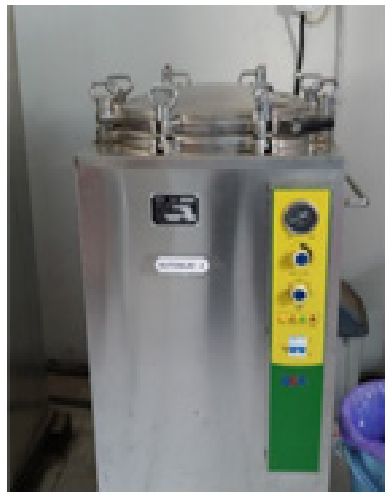

C

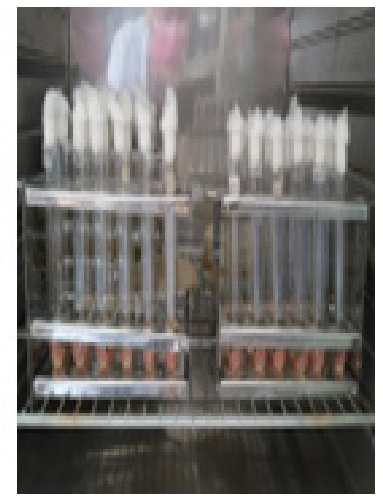

D

Gambar 2. A. Mould space diisi dengan bahan nilon termoplastik; B. Cakram nilon termoplastik yang telah terbentuk dirapikan tanpa dilakukan pemolesan; C. Cakram nilon termoplastik disterilisasi menggunakan autoclave pada suhu $121^{\circ} \mathrm{C}$ selama 15 menit; D. Cakram nilon termoplastik direndam serta diinkubasi selama 24 jam.(Sumber: Dokumentasi pribadi) 


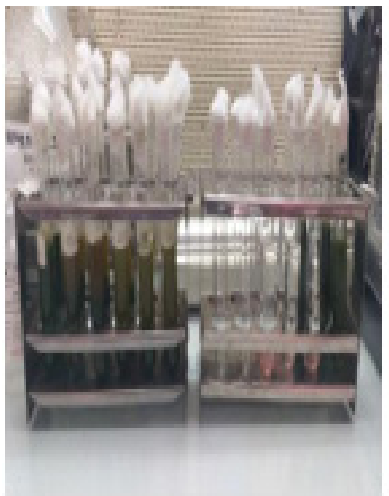

A

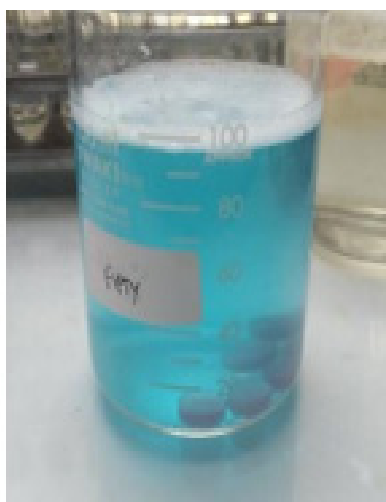

B

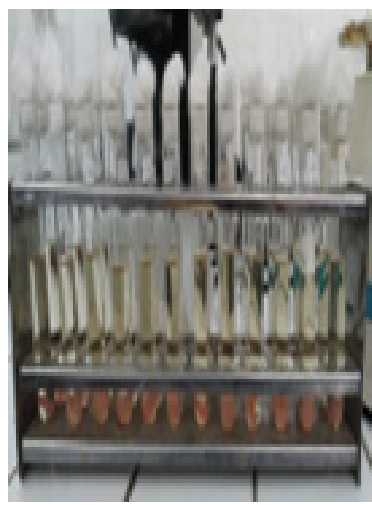

C

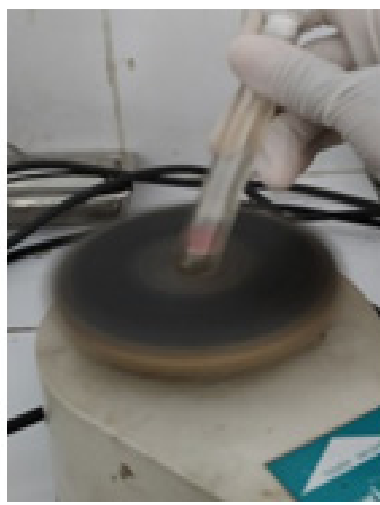

D

Gambar 3. A. Cakram nilon termoplastik direndam dalam kontrol negatif dan perasan daun seledri 25,50 , dan $100 \%$ selama 6 jam. B. Cakram nilon termoplastik direndam dalam kontrol positif selama 15 menit; C. Cakram nilon termoplastik direndam dalam media SDB; D. Cakram nilon termoplastik divibrasi menggunakan vortex.(Sumber: Dokumentasi pribadi)

wilayah Jember yang berumur 2-4 bulan sebanyak 500 gram dalam keadaan segar dan dicuci hingga bersih. Daun seledri dipotong dan dikeringkan dengan cara diangin-anginkan di tempat yang tidak terkena sinar matahari langsung selama 1 hari. Daun seledri diiris hingga ketebalan $\pm 2 \mathrm{~mm}$ dan dilumat menggunakan blender tanpa menggunakan air. Lumatan diperas menggunakan kain flanel dan sari yang diperoleh ditampung hingga didapatkan volume sebanyak $60 \mathrm{~mL}$. Air perasan daun seledri yang diperoleh yaitu konsentrasi $100 \%$ yang nantinya akan diencerkan menggunakan rumus $\mathrm{V} 1 \mathrm{xN} 1=\mathrm{V} 2 \mathrm{xN} 2$ untuk mendapatkan konsentrasi 25 dan $50 \% .^{13}$

Cakram kemudian dibilas kembali menggunakan PBS sebanyak 2 kali, kemudian direndam pada media sabouraud dextrose broth
(SDB) dan divibrasi dengan vortex (Gambar 3C dan 3D). ${ }^{22}$ Cakram kemudian diuji keefektivitasannya dengan menentukan absorbansi kekeruhan media SDB di panjang gelombang $560 \mathrm{~nm}$ menggunakan

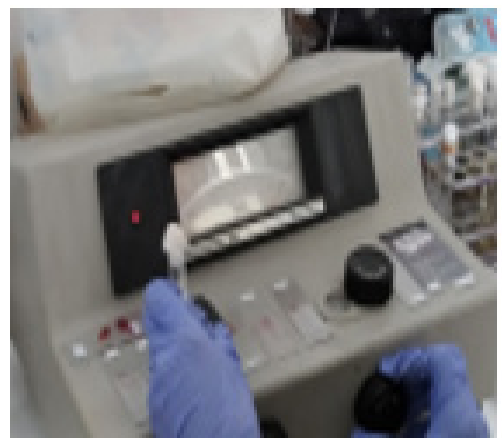

Gambar 4. Cakram nilon termoplastik dilakukan pengujian efektivitas dengan menggunakan spektrofotometer.

(Sumber: Dokumentasi pribadi)

Tabel 1. Nilai absorbansi media SDB dengan C. albicans pada pembacaan spektrofotometer

\begin{tabular}{lccccccc}
\hline \multirow{2}{*}{ Kelompok } & \multicolumn{4}{c}{ Nilai absorbansi C. albicans pada sampel } & \multirow{2}{*}{ Rerata } & Simpangan Baku \\
\cline { 2 - 6 } & 1 & 2 & 3 & 4 & 5 & & 0,004 \\
Kontrol negatif & 0,038 & 0,035 & 0.0400 & 0,045 & 0,035 & 0,039 & 0,004 \\
Kontrol positif & 0,039 & 0,033 & 0,030 & 0,030 & 0,034 & 0,033 & 0,001 \\
Perasan daun seledri 25\% & 0,028 & 0,029 & 0,027 & 0,028 & 0,030 & 0,028 & 0,003 \\
Perasan daun seledri 50\% & 0,018 & 0,020 & 0,025 & 0,023 & 0,025 & 0,022 & 0,005 \\
Perasan daun seledri 100\% & 0,035 & 0,030 & 0,023 & 0,025 & 0,026 & 0,028 & \\
\hline
\end{tabular}

Tabel 2. Nilai konsentrasi C. albicans pada basis gigi tiruan nilon termoplastik yang direndam media SDB

\begin{tabular}{|c|c|c|c|c|c|c|c|}
\hline \multirow{2}{*}{ Kelompok } & \multicolumn{5}{|c|}{ 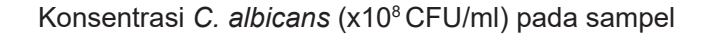 } & \multirow{2}{*}{ Rerata } & \multirow{2}{*}{ Simpangan Baku } \\
\hline & 1 & 2 & 3 & 4 & 5 & & \\
\hline Kontrol negatif & 0,367 & 0,333 & 0,400 & 0,467 & 0,333 & 0,380 & 0,056 \\
\hline Kontrol positif & 0,387 & 0,307 & 0,267 & 0,267 & 0,320 & 0,310 & 0,049 \\
\hline Perasan daun seledri $25 \%$ & 0,240 & 0,253 & 0,227 & 0,233 & 0,260 & 0,243 & 0,014 \\
\hline Perasan daun seledri $50 \%$ & 0,100 & 0,133 & 0,200 & 0,167 & 0,200 & 0,160 & 0,044 \\
\hline Perasan daun seledri $100 \%$ & 0,333 & 0,267 & 0,167 & 0,200 & 0,213 & 0,236 & 0,065 \\
\hline
\end{tabular}


spektrofotometer, kemudian nilai absorbansi diukur dengan larutan standar Mc. Farland 0,5 yang akan dikonversikan ke dalam rumus Stainer untuk mengetahui jumlah C. albicans (Gambar 4). ${ }^{24}$

HASIL

Tabel 1 menunjukkan nilai absorbansi $C$. albicans kelompok kontrol negatif 0,039 , kelompok kontrol positif 0,033 , kelompok perasan daun seledri $25 \%, 0,028$; kelompok perasan daun seledri $50 \%, 0,022$; dan kelompok perasan daun seledri $100 \%, 0,028$.

Tabel 2 menunjukkan nilai konsentrasi $C$. albicans yang terbesar terdapat pada kelompok

Tabel 3. Hasil uji normalitas menggunakan uji Shapiro-Wilk

\begin{tabular}{lccc}
\hline \multirow{2}{*}{ Kelompok } & \multicolumn{3}{c}{ Shapiro-Wilk } \\
\cline { 2 - 4 } & Statistik & df & Nilai p \\
\hline Kontrol negatif & 0,882 & 5 & 0,318 \\
Kontrol positif & 0,880 & 5 & 0,309 \\
$\begin{array}{c}\text { Perasaan daun seledri } \\
\text { konsentrasi 25\% }\end{array}$ & 0,951 & 5 & 0,743 \\
$\begin{array}{c}\text { Perasaan daun seledri } \\
\text { konsentrasi 50\% }\end{array}$ & 0,901 & 5 & 0,416 \\
$\begin{array}{c}\text { Perasaan daun seledri } \\
\text { konsentrasi 100\% }\end{array}$ & 0,944 & 5 & 0,693 \\
\hline
\end{tabular}

kontrol negatif sebesar $0,380 \times 10^{8} \mathrm{CFU} / \mathrm{mL}$, sedangkan konsentrasi yang paling kecil terdapat pada kelompok perasan daun seledri konsentrasi $50 \%$ sebesar $0,160 \times 10^{8} \mathrm{CFU} / \mathrm{mL}$.

Tabel 3 merupakan hasil uji normalitas
Tabel 4. Hasil uji homogenitas menggunakan uji Levene

\begin{tabular}{cccc}
\hline Levene Statistic & df1 & df2 & Nilai $\mathbf{p}$ \\
\hline 1,791 & 4 & 20 & 0,170 \\
\hline
\end{tabular}

menggunakan uji Shapiro-Wilk $(p>0,05)$ yang menunjukkan bahwa data berdistribusi normal. Data selanjutnya dilakukan uji homogenitas menggunakan uji Levene.

Tabel 4 merupakan hasil uji homogenitas menggunakan uji Levene $(p>0,05)$ yang

Tabel 5. Hasil uji beda menggunakan uji one-way ANOVA

\begin{tabular}{ccccc}
\hline $\begin{array}{c}\text { Sum of } \\
\text { squares }\end{array}$ & df & $\begin{array}{c}\text { Mean } \\
\text { square }\end{array}$ & F & Nilai p \\
\hline 0,138 & 4 & 0,034 & 14,492 & 0,0001 \\
0,048 & 20 & 0,002 & & \\
0,185 & 24 & & & \\
\hline
\end{tabular}

menunjukkan bahwa data berdistribusi homogen. Data yang berdistribusi normal dan homogen selanjutnya dilakukan uji parametrik menggunakan uji one-way ANOVA.

Tabel 5 merupakan hasil uji parametrik menggunakan uji one-way ANOVA $(p>0,05)$ yang menunjukkan bahwa terdapat perbedaan pada masing-masing kelompok. Data selanjutnya dilakukan uji lanjutan untuk mengetahui letak perbedaan pada masing-masing kelompok dengan menggunakan uji Least Significant Difference (LSD).

Tabel 6 merupakan hasil uji LSD yang menunjukkan bahwa $p<0,05$ yang berarti terdapat

Tabel 6. Hasil uji beda lanjutan menggunakan uji Least Significant Difference (LSD)

\begin{tabular}{|c|c|c|c|c|c|}
\hline \multirow[b]{2}{*}{ Kelompok } & \multicolumn{5}{|c|}{ Nilai $p$} \\
\hline & Kontrol negatif & Kontrol positif & $\begin{array}{c}\text { Perasan daun } \\
\text { seledri } 25 \%\end{array}$ & $\begin{array}{c}\text { Perasan daun } \\
\text { seledri } 50 \%\end{array}$ & $\begin{array}{l}\text { Perasan daun } \\
\text { Seledri } 100 \%\end{array}$ \\
\hline Kontrol Negatif & - & $\left.0,034^{*}\right)$ & $0,001^{(*)}$ & $0,001^{(*)}$ & $\left.0,001^{*}\right)$ \\
\hline Kontrol Positif & $0,034^{(*)}$ & - & $0,042^{(*)}$ & $0,001^{(*)}$ & $0,027^{(*)}$ \\
\hline Perasan Daun Seledri 25\% & $0,001^{(*)}$ & $0,042^{(*)}$ & - & $0,014^{(*)}$ & 0,833 \\
\hline Perasan Daun Seledri 50\% & $0,001^{(*)}$ & $0,001^{(*)}$ & $0,014^{(*)}$ & - & $0,023^{(*)}$ \\
\hline Perasan Daun Seledri 100\% & $0,001^{(*)}$ & $0,027^{(*)}$ & 0,833 & $0,023^{(*)}$ & - \\
\hline
\end{tabular}

Keterangan: ${ }^{(*)}=$ nilai signifikan kurang dari 0,05 .

perbedaan bermakna pada seluruh kelompok perlakuan, kecuali pada kelompok perasan daun seledri $25 \%$ dan perasan daun seledri $100 \%$ didapatkan hasil $p>0,05$.

\section{PEMBAHASAN}

Berdasarkan hasil pengukuran menggunakan alat spektrofotometer, kelompok kontrol negatif (aquades) menunjukkan nilai konsentrasi $C$. albicans terbesar sebesar $0,380 \mathrm{x}$ $10^{8} \mathrm{CFU} / \mathrm{mL}$. Ardelia ${ }^{13}$ menyatakan bahwa aquades tidak menghasilkan zona hambat $C$. albicans pada cakram nilon termoplastik, sehingga sesuai dengan pernyataan tersebut maka akuades pada 
penelitian ini memang tidak memiliki pengaruh dalam menghambat pertumbuhan C. albicans pada cakram nilon termoplastik. Hal ini disebabkan aquades tidak bersifat bakterisid ataupun bakteriostatik yang di dalamnya tidak mengandung zat aktif untuk menghambat pertumbuhan $C$. albicans.

Kelompok kontrol positif (tablet effervescent) menunjukkan nilai konsentrasi $C$. albicans lebih kecil dari kontrol negatif, yaitu $0,310 \times 10^{8} \mathrm{CFU} /$ $\mathrm{mL}$ berarti terdapat pengaruh dalam menghambat pertumbuhan C. albicans. Hal ini disebabkan tablet effervescent memiliki zat aktif seperti sodium bikarbonat dan asam sitrat yang akan berubah menjadi gelembung gas akibat bereaksi dengan air sehingga dapat memberikan efek pembersihan secara kimiawi pada cakram nilon termoplastik. ${ }^{25,26}$

Perendaman cakram nilon termoplastik dengan perasan daun seledri konsentrasi 25, 50 , dan $100 \%$ menghasilkan nilai yang berbeda. Semakin tinggi konsentrasi perasan daun seledri yang digunakan maka kandungan yang bersifat antijamur akan bereaksi lebih cepat membunuh $C$. albicans. ${ }^{27}$ Perbedaan yang terjadi dapat disebabkan oleh faktor lain yaitu adanya perbedaan viskositas (kekentalan) dan berat jenis cairan. Menurut Madan dan $\mathrm{Singh}^{28}$, semakin tinggi konsentrasi yang digunakan, maka semakin tinggi pula viskositasnya. ${ }^{28}$ Aziz dkk. ${ }^{29}$ juga menyatakan bahwa semakin tinggi konsentrasi yang digunakan maka nilai berat jenisnya semakin tinggi pula. ${ }^{29}$

Perasan daun seledri $25 \%$ memiliki nilai konsentrasi C. albicans sebesar 0,243 x 108 CFU/ Ml berarti memiliki nilai paling kecil dibandingkan konsentrasi yang lain. Ardelia dkk. ${ }^{13}$ menyatakan bahwa perasan daun seledri $25 \%$ menghasilkan zona hambat $C$. albicans pada cakram nilon termoplastik, sehingga sesuai dengan pernyataan tersebut maka perasan daun seledri $25 \%$ pada penelitian ini memang memiliki pengaruh dalam menghambat pertumbuhan C. albicans pada cakram nilon termoplastik. Konsentrasi ini juga dikatakan sebagai konsentrasi yang memiliki viskositas dan berat jenis yang rendah sehingga paling mudah mengalami difusi, tetapi kandungan antijamur yang dimiliki rendah sehingga reaksi akan berlangsung lebih lambat.

Perasan daun seledri $50 \%$ memiliki nilai konsentrasi $C$. albicans terkecil, yaitu sebesar $0,160 \times 10^{8} \mathrm{CFU} / \mathrm{mL}$. Ardelia dkk. ${ }^{13}$ menyatakan bahwa perasan daun seledri 50\% menghasilkan zona hambat $C$. albicans pada cakram nilon termoplastik, sehingga sesuai dengan pernyataan tersebut maka perasan daun seledri $50 \%$ pada penelitian ini memang memiliki pengaruh dalam menghambat pertumbuhan $C$. albicans pada cakram nilon termoplastik. Konsentrasi ini juga dikatakan sebagai konsentrasi yang memiliki viskositas dan berat jenis yang cukup tinggi sehingga zat aktif akan mengalami difusi dengan kandungan antijamur yang dimiliki juga cukup tinggi sehingga reaksi akan berlangsung optimal.

Perasan daun seledri $100 \%$ memiliki nilai konsentrasi C. albicans sebesar 0,236 x 108 CFU/ MI. Ardelia dkk. ${ }^{13}$ menyatakan bahwa perasan daun seledri $100 \%$ menghasilkan zona hambat $C$. albicans pada cakram nilon termoplastik, sehingga sesuai dengan pernyataan tersebut maka perasan daun seledri $100 \%$ pada penelitian ini memang memiliki pengaruh dalam menghambat pertumbuhan $C$. albicans pada cakram nilon termoplastik. Konsentrasi ini juga dikatakan sebagai konsentrasi yang memiliki viskositas dan berat jenis yang tinggi sehingga kandungan antijamur yang tinggi pada konsentrasi ini tidak bereaksi secara optimal karena proses difusi berlangsung lebih lambat. Pernyataan diatas dapat disimpulkan bahwa konsentrasi perasan daun seledri $50 \%$ adalah konsentrasi yang paling efektif dalam menghambat pertumbuhan $C$. albicans pada cakram nilon termoplastik.

Konsentrasi perasan daun seledri yang optimal tersebut (50\%) juga dapat dipengaruhi oleh proses dilusi (pengenceran) yang dilakukan. Proses dilusi pada penelitian ini menggunakan air yang berfungsi sebagai zat pelarut (pendispersi) yang akan bekerja sebagai agen pembawa zat aktif yang berada pada perasan daun seledri (terdispersi). Rini dkk. ${ }^{30}$ menyatakan bahwa semakin larut zat aktif dalam agen pembawa maka semakin cepat pula proses difusi yang berjalan. ${ }^{30}$

Hasil ini juga didukung oleh penelitian Ardelia dkk. ${ }^{17}$ yang menyatakan bahwa perlakuan perasan daun seledri terhadap $C$. albicans dengan konsentrasi $100 \%$ justru memberikan daerah hambat yang lebih kecil dibandingkan perasan daun seledri $50 \%$, sedangkan untuk konsentrasi perasan $25 \%$ tidak memberikan daerah hambat. ${ }^{13}$ Penelitian lain yang telah dilakukan oleh Shad dkk. ${ }^{19}$ menyatakan bahwa seledri mempunyai 
potensi antijamur terhadap Trichphyton longifuss, Candida albicans, Aspergillus flavus, Microsporum canis, Fusarium solani, dan Candida glabrata. ${ }^{19}$ Mekanisme antijamur yang dimiliki oleh perasan daun seledri dipengaruhi oleh adanya zat aktif yang dimiliki, yaitu flavonoid $1,7 \%$, saponin $0,36 \%$, tanin $1 \%$, dan minyak atsiri $0,33 \%$ yang diduga dapat memberikan efek antijamur. ${ }^{18}$ Flavonoid sebagai antijamur dapat menyebabkan gugus hidroksil pada salah satu cincin aromatik flavonoid akan berikatan dengan struktur fosfolipid dinding sel jamur sehingga terjadi perubahan struktur dinding sel jamur. Hal ini akan menyebabkan permeabilitas terganggu dan proses difusi juga akan terganggu sehingga akan menyebabkan jamur mati. .11,32,33

Saponin sebagai antijamur dapat menyebabkan kebocoran protein dan enzim dari dalam sel jamur. Saponin dapat menjadi zat aktif antijamur karena permukaannya mirip detergen, sehingga saponin dapat menurunkan tegangan permukaan dinding sel jamur dan akan merusak permeabilitas dari membran sel. Rusaknya membran sel akan mengganggu kelangsungan hidup jamur. Saponin berdifusi melalui membran luar dan dinding sel yang rentan kemudian mengikat membran sitoplasma sehingga mengganggu kestabilan membran sel. Hal ini menyebabkan sitoplasma bocor keluar dari sel yang mengakibatkan kematian sel. ${ }^{34}$ Saponin yang bersifat ampifilik juga dapat membantu ikatan zat aktif yang larut dalam air dengan membran sel. ${ }^{35}$ Saponin juga dapat meningkatkan reactive oxygen species (ROS) endogen yang dapat merusak sel DNA, protein, dan dinding sel yang dapat menyebabkan kematian sel. ${ }^{36}$

Tanin sebagai antijamur bersifat antimikroba karena memiliki senyawa astrigen. Senyawa astringen dari tanin diduga dapat mengganggu permeabilitas sel. Gangguan permeabilitas membuat aktivitas sel menjadi terganggu sehingga sel menjadi rapuh dan akhirnya mati. ${ }^{37}$

Minyak atsiri sebagai anti jamur merupakan zat aktif yang akan menyerang ergosterol pada membran sel jamur $C$. albicans sehingga menyebabkan perubahan permeabilitas membran dan kerusakan membran yang akhirnya molekulmolekul sel jamur $C$. albicans akan keluar sehingga menyebabkan kematian sel. ${ }^{38}$

Zat aktif pada perasan daun seledri selain memberikan efek antijamur juga dapat berpengaruh pada sifat fisik dari basis gigi tiruan nilon termoplastik yang digunakan. Zat aktif flavonoid yang diduga bersifat asam mengakibatkan kekasaran permukaan pada basis gigi tiruan nilon termoplastik apabila digunakan dalam jangka waktu yang panjang. ${ }^{39}$ Senyawa flavonoid yang merupakan senyawa golongan fenol dapat menjadi penyebab terjadinya degradasi polimer karena dapat melarutkan suatu basis gigi tiruan berbahan dasar resin..$^{40}$

Zat aktif flavonoid juga bisa menyebabkan perubahan warna karena bahan nilon termoplastik bersifat mudah melakukan penyerapan cairan, hal ini didukung oleh pernyataan oleh Anusavice dkk. $^{20}$ yang menyatakan bahwa nilon termoplastik yang berkontak dengan cairan umumnya akan terjadi penyerapan cairan atau terjadi difusi atau berpindahnya suatu substansi melalui rongga. ${ }^{20}$

\section{SIMPULAN}

Perasan daun seledri efektif sebagai pembersih gigi tiruan untuk menghambat pertumbuhan $C$. albicans, dengan konsentrasi yang efektif sebesar $50 \%$.

\section{DAFTAR PUSTAKA}

1. Kemenkes RI. Riset Kesehatan Dasar. Badan Penelitian dan Pengembangan Kesehatan. Jakarta: Departemen Kesehatan, Republik Indonesia.; 2018. p. 185.

2. Siagian KV. Kehilangan sebagian gigi pada rongga mulut. J e-Clinic (eCl). 2016;4(1):1-6. DOI: $10.35790 / \mathrm{ecl} .4 .1 .2016 .12316$.

3. Laoh MH, Siagian K, Tocoalu S. Status gingiva pada pasien pengguna gigi tiruan cekat di RSGM PSPDG Fakultas Kedokteran Universitas Sam Ratulangi Manado. J e-Gigi (eG). 2016;4(2):196-201. DOI: 10.35790/ eg.4.2.2016.13927

4. Ozkan YK. Attachment and Their Use in Removable Partial Denture. Ann Arbor: University of Michigan. 2012. p. 56

5. Setiawan R. Penatalaksanaan relining pada gigi tiruan sebagian lepasan (GTSL). J IImiah WIDYA. 2013;1(1):60-4.

6. Yamamoto T, Kondo K, Aida J, Suzuki K, Misawa J, Nakade M, dkk. Social determinants of denture or bridge use: Japan gerontological 
evaluation study project cross-sectional study in older Japanese. BMC Oral Health. 2014;14(63):1-11. DOI: 10.1186/1472-683114-63

7. Ireland R. Dictionary of Dentistry. London: OUP Oxford; 2010. p. 34

8. Naini A. Perbedaan stabilitas warna basis gigi tiruan resin akrilik dengan resin nilon termoplastik terhadap penyerapan cairan. J Ked Gigi Unej. 2012;9(1):28-32.

9. Sheeba G, Arun KG. A comparative evaluation of flexural properties of flexible denture base material and compression molded heat polymerized denture base material an in vitro study. Kerala Dent J. 2010;33(4):213-5.

10. Sharma AHSS. A Review: Flexible removable partial dentures. J Dent Med Sci. 2014;13(12):58-62. DOI: 10.9790/0853131265862

11. Wurangian I. Aplikasi dan desain valpast pada gigi tiruan sebagian lepasan. J IImiah TKG. 2010;7(2):63-68.

12. Takabayashi Y. Charateristic of denture thermoplastic resins for non-metal clasp dentures. Dent Mater J. 2010;29(4):353-361.

13. Ardelia PI, Andrini F, Hamidy MY. Aktivitas antijamur air perasan daun seledri (Apium graveolens L.) terhadap Candida albicans secara in vitro. J IImu Ked. 2010;4(2):102-7. DOI: 10.26891/JIK.v4i2.2010.102-107

14. Krisma W, Mozartha M, Rani R. Level of denture cleanliness influences the presence of denture stomatitis on maxillary denture bearingmucosa. J Dent Indonesia. 2014;21(2):44-48.

15. Prabha MM, Anoop A. In vitro study on the efficacy of herbal mouthwash or mouth rinse against selected oral pathogens. World $\mathrm{J}$ Pharm Res. 2015;4(11):1148-57.

16. Cortelli SC, Costa FO, Rode SM, Haas AN, Andrade AKP, Pannuti CM, dkk. Mouthrinse recommendation for prosthodontic patients. Braz Oral Res. 2014;28(1):1-9. DOI: 10.1590/1807-3107BOR-2014.vol28.0020

17. Dewo M. Gendola Obat Dewa Penakluk Aneka Penyakit. Jakarta: Fmedia; 2013. p. 14.

18. Hofling JF, Mardegan RC, Anibal PC, Furlettti VF, Voglio MA. Evaluation of antifungal activity of medical plant extract against oral Candida albicans and proteinase. Mycopathologia. 2011;172(2):117-124. DOI: 10.1007/s11046- 011-9404-z

19. Shad AA, Shah HU, Bakht J, Choudhary MI, Ullah J. Nutraceutical potential and bioassay of Apium graveolens L. grown in khyber Pakhtunkhwa-Pakistan. J Med Plants. 2011;5(20):5160-6.

20. Anusavice KJ, Shen C, Rawls HR. Phillips' Science of Dental Materials. St. Louis, Missouri: Elsevier; 2013. p. 489.

21. Sundari I, Sofya PA, Hanifa M. Studi kekuatan fleksural antara resin akrilik heat cured dan termoplastik nilon setelah direndam dalam minuman kopi Ulee kareng (Coffea robusta). J Syiah Kuala Dent Soc. 2016;1(1):51-8.

22. Pambudi RR, Sulistyorini R, Mayasari LO. 2017. Perbedaan Perendaman Cakram Resin Akrilik Pada Tablet Pembersih Gigi Tiruan Effervescent Dan Air Rebusan Daun Sirih Terhadap Penurunan Jumlah Koloni Candida Albicans. Prosiding Seminar Nasional Publikasi Hasil-Hasil Penelitian dan Pengabdian Masyarakat; 2017 Sep 30; Semarang, Indonesia. Universitas Muhammadiyah Semarang; 2017. h. 26

23. Dahar E, Chandra D. Perubahan warna lempeng resin akrilik yang direndam dalam larutan desinfektan sodium hipoklorit dan klorheksidin. Majalah Ked Gigi (Dent J). 2014;38(1):36-40.

24. Sari SP, Achmad G, Dewi K. Efektivitas perasan daun kemangi (Ocimum basilicum) dibanding larutan pembersih gigi tiruan effervescent sebagai pembersih gigi tiruan resin akrilik terhadap pertumbuhan Candida albicans. E-J Pustaka Kes. 2019;7(2):135-41.

25. De Andrade IMH, Cruz PC, da Silva CHL, de Souza RF, de Freitas OPH, Candido RC, dkk. Effervescent tablets and ultrasonic devices against Candida and Streptococci mutans in denture biofilm. J Gerodontology. 2011;28(4):264-70. DOI: 10.1111/j.17412358.2010.00378.x

26. Suni NA, Wowor VNS, Leman MA. Uji daya hambat rebusan daun pepaya (Carica papaya) terhadap pertumbuhan Candida albicans pada cakram resin akrilik polimerisasi panas. J e-Gigi (eG). 2017;5(1):74-8.

27. Muchlisyiyah J, Laeliocat RA, Putri WDR. Kimia Fisik Pangan. Malang: Universitas Brawijaya Press.; 2017. p. 35. 
28. Madan J, Singh R. Formulation and evaluation of Aloe vera topical gels. Int J Pharm Sci. 2010;2(2):551-15.

29. Aziz T, Yuanita, Susanti. Ekstrasi eugenol dari daun salam India (Laurus nobilis lauraceae). J Tek Kim. 2010;3(17):17-28.

30. Rini A, Sari N, Zaini E. Pelepasan ibuprofen dari gel karbomer 940 kokristal ibuprofen-nikotinamida. J Sains Farma dan Klinis. 2014;1(1):79-88. DOI: 10.29208/ jsfk.2014.1.1.15

31. Christoper W, Natalia D, Rahmayanti S. Uji aktivitas antijamur ekstrak etanol umbi bawang dayak uji aktivitas antijamur ekstrak etanol umbi bawang dayak (Eleutherine americana (Aubl.) Merr. Ex K. Heyne.) terhadap (Eleutherine americana (Aubl.) Merr. Ex K. Heyne.) terhadap Trichophyton mentagro. J Kes Andalas. 2017;6(3):685-9. DOI: 10.25077I jka.v6i3.758

32. Arifin Z, Khotimah S, Rahmayanti S. Aktivitas antijamur ekstrak etil asetat daun mangga bacang (Mangifera foetida L.) terhadap Candida albicans secara in vitro. J Cerebellum. 2018;4(3):1106-19.

33. Dewi S, Sutikno, Neti Y, Maghfiroh SR. 2019. Identifkasi senyawa antimikroba alami pangan pada ekstrak kulit buah naga merah dengan menggunakan GC-MS. J Tek dan Industri Hasil Pert. 2019;24(2):67-76. DOI: 10.23960/jtihp. v24i2.67-76

34. Lorent JH, Quetin-Leclerq J, Mingeot-Leclercq MP. The amphiphilic nature of saponins and their effects on artificial and biological membranes and potential consequences for red blood and cancer cells. Org Biomol Chem. 2014;12(44):8803-22. DOI: 10.1039/ c4ob01652a

35. Korchowiec B, Gorczyca M, Wojszko K, Janikowska M, Henry M, Rogalska E. Impact of two different saponins on the organization of model lipid membranes. Biochi et Biophy Acta J. 2015;2015(10):1963-73. DOI: 10.1016/j. bbamem.2015.06.007

36. Yang L, Liu X, Zhuang X, Feng X, Zhong L, Ma T. Antifungal effects of saponin extract from rhizomes of dioscorea panthaica prain et burk against Candida albicans. Evid-Based Complementary Altern Med. 2018;2018:1-14. DOI: $10.1155 / 2018 / 6095307$

37. Widayat MM, Purwanto P, Shita ADP. Daya antibakteri infusa kulit manggis (Garcinia mangostana L) terhadap Streptococcus mutans (antibacterial of mangosteen peel infuse (Garcinia Mangostana L) against Streptococcus mutans). E-J Pustaka Kes. 2017;4(3):514-8.

38. Wulandari D. Isolasi dan Uji Aktivitas Antimikroba Ekstrak Etanol Propolis Trigona spp [skripsi]. Sulawesi Tenggara: Fakultas MIPA, Universitas Halu Oleo.; 2016. h. 50

39. Daulay AY, Ningsih DS, Diansari V. Pengaruh durasi resin akrilik heat cured dalam minuman kopi Ulee kareng terhadap perubahan dimensi. Cakradonya Dent J. 2012;4(2):475-542.

40. Amiliyah R, Sumono A, Hidayati L. 2015. Deformasi plastis nilon termoplastik setelah direndam dalam ekstrak biji kopi robusta. E-J Pustaka Kes. 2015;3(1):117-21. 